\title{
Authentic Semi-precious and Precious Gemstones of Turkey: Special Emphasis on the Ones Preferred for Prayer Beads
}

\author{
E. Çiftçi ${ }^{1(\bowtie)}$, H. Selim ${ }^{2}$, and H. Sendir ${ }^{3}$ \\ ${ }^{1}$ Department of Geological Engineering, Faculty of Mines, ITU, 33469 Maslak, \\ Istanbul, Turkey \\ eciftci@itu.edu.tr \\ ${ }^{2}$ Faculty of Engineering, Department of Jewellery Engineering, ITICU, \\ 34840 Küęükyalı, Istanbul, Turkey \\ 3 Faculty of Engineering and Architecture, Department of Geological \\ Engineering, EOGU, 26480 Odunpazarı, Eskișehir, Turkey
}

\begin{abstract}
There are 6 semi-precious gemstones in Turkey that are the most significant in terms of abundance and authenticity. These include smoky quartz, blue chalcedony, chrysoprase (aka Şenkaya emerald), diaspore (aka sultanite/zultanite), sepiolite (aka meerschaum/Eskişehirstone), and jet (aka Oltustone). The smoky quartz occurs in the south of Büyük Menderes Basin within metamorphic rocks of the massif. Chalcedony occurrences are in Çanakkale and Sarıcakaya (Eskişehir). Chrysoprase is acquired in Bursa, Alaşehir (Manisa) as yellowish green in color, Biga (Çanakkale), Sivrihisar (Eskişehir) and Șenkaya (Erzurum) as dark green in color. Diaspore occurs in Milas (Muğla), Söke (Aydın), Tire (İzmir), Bolkardağı Gerdekkilise area and Saimbeyli (Adana). Sepiolite occurrences are limited to Kıbrısçık-Köroğlu (Bolu), Eskişehir and Konya. Jet (aka Oltustone) occurs in Oltu area (Erzurum). These are the major varieties that has been used to produce both jewelry and ornamental objects among which the prayer beads are one of the most indispensable object of oriental cultures in particular. These are also considered to be the authentic gems of Turkey and exported as raw and processed in into many forms. As for the prayer beads, lightness, color, durability, hardness, and cost are the main criteria. Thus, the Oltustone has been the major source for decades. However, the Eskişehir stone and blue chalcedony are becoming popular as well.
\end{abstract}

Keywords: Turkish gems $\cdot$ Oltustone $\cdot$ Eskișehirstone $\cdot$ Diaspore $\cdot$ Smoky quartz $\cdot$ Blue chalcedony

\section{Introduction}

Today, the jewelry sector is living its golden age. With increasing technical capacity and manual aptitude, gold, silver, platinum etc. metals can be embroidered with the precious and semi-precious gems and delivered to consumers. This sector is a fashiondriven dynamic sector and subjected to rapid changes and innovations that are controlled and dictated by the fashion trends and demands of the consumers. Companies 
are forced to keep up with those and both develop and manufacture the products accordingly. Use of the semi-precious and precious gems is likewise chosen according to the demand by the fashion and modern trends. Consumers religiously follow those two facts. Some of those are considered to be semi-precious gems of Turkey including smoky quartz, chalcedony, chrysoprase, diaspore, sepiolite, and jet (Selim 2015).

\section{Methods and Approaches}

Representative samples that acquired from the deposits were prepared for further analytical studies for comprehensive characterization. Polished sections and powdered samples were prepared for Transmitted and Reflected Light Microscopy integrated with Optical Cathodoluminescence, Electron Probe Microanalysis (EPMA) and Secondary Electron Microscopy-Energy Dispersive Spectroscopy (SEM-EDS), X-ray Diffraction (XRD), X-ray Fluorescence (XRF) and Inductively-Coupled Plasma Mass Spectroscopy analyses.

\section{Results and Discussion}

\subsection{Smoky Quartz}

Smoky quartz is one of the varieties of quartz with dark gray-black color (Fig. 1). It occurs rarely in the Alps, Colorado and California (North America). Its occurrence in Turkey is limited to the Menderes Massif, one of the metamorphic complexes of Turkey. It occurs in metamorphic rocks composed of mafic minerals that expose in southern portion of the massif in Great Menderes basin (İlhan 2012). Location is the city of Aydın and covers a few rustic villages within Çine, Ovacık and Koçarlı county limits. Host-rocks are variable degree metamorphic rocks including slate, phyllite, schist, and gneiss. Smoky quartz occurs locally within the fractures of these rocks. Its major use is as jewelry and ornamental objects. Type locality is Mersinbelen village in the area.
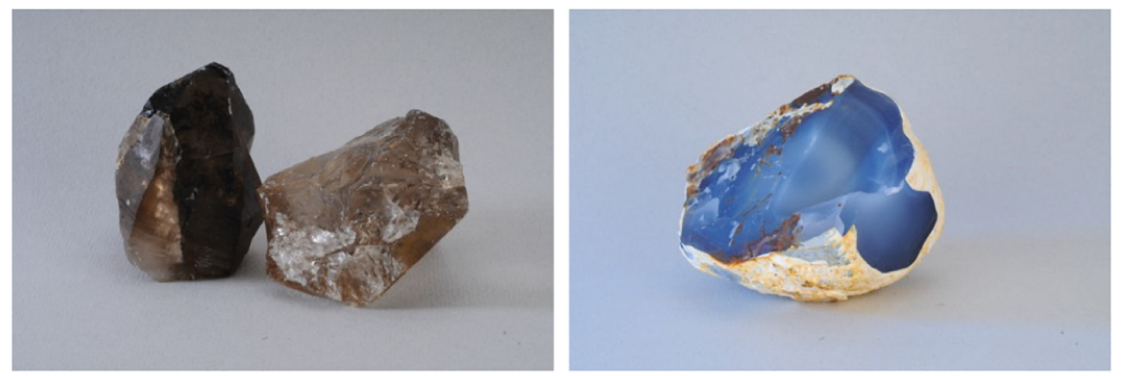

Fig. 1. Macroscopic views of natural smoky quartz and blue chalcedony (Selim 2015) 


\subsection{Chalcedony}

Chalcedony occurs in a few locations including Bolu (Kıbrısçık), Ankara (Beypazarı), Afyon (Bayat), İzmir (Aliağa, Bergama, Seferihisar-Yukarıdoğanbey), Tokat (Zile) in lilac-purple colors, Yozgat (Çekerek) with amethyst as botryoidal masses, Çanakkale (center) and Eskișehir (Sarıcakaya) in blue color. Druzy chalcedony occurs in Sivas (Ylldizeli) (Illhan 2012). Chalcedony is a silica variety mineral. Its color may vary from deep blue to faint blue, purple in places, translucent and opaque (Fig. 1). Among these, blue chalcedony occurrence in Turkey is located in Mayıslar village (SarıcakayaEskişehir) owned and exploited by Kalsedon Co. (Hatipoğlu et al. 2010a). Blueish color is either due to the water content or abnormally high barium content. This is also considered to be the type locality. Its major use is as jewelry and ornamental objects.

\subsection{Chrysoprase}

Chrysoprase or chrysoprasus is a gemstone variety of chalcedony that contains small quantities of nickel. The color varies from faint light green to apple green (Fig. 2). It is translucent and opaque. It worldwide occurrences are reported from USA (California, Oregon, and Arizona) and Eastern India. In Turkey, it occurs in Alaşehir (Manisa) in yellowish green, Dikmendağı area in Biga (Çanakkale) deep green, Sivrihisar (Eskişehir) in deep green, İkizce village (Bursa), Zümrüt and Turnalı villages of Şenkaya county (Erzurum). In Erzurum, due to it locality and most probably to the color, it is erroneously named as "Şenkaya Emerald". It has naturally formed patterns and quasi figures that make small objects even more fascinating.


Fig. 2. Macroscopic views of natural chrysoprase and diaspore (Selim 2015)

\subsection{Diaspore}

Diaspore is one of the minerals forming the bauxite ore. It is the least hydrous Aloxyhydroxide mineral in the bauxites. Diaspore becomes the main, even only mineral of bauxites when the bauxite ore gets metamorphosed. Such ores are better called as diasporite, since those are monomineralic. This is very common occurrence especially in the Menderes Massif (western Anatolia). Diaspore crystals sometimes grow into really gigantic sizes. Then becomes gem material. Diaspore naturally occur in yellowish green and light green colors (Fig. 2). In addition to the metabauxites, diaspore 
occurrences are also reported in laterites and Al-rich clays, in recrystallized limestones, with corundum, in some alkali pegmatites as late stage hydrothermal mineral, and in magmatic rocks as a result of recrystallization of Al-rich xenoliths (Hatipoğlu et al. 2010b; Kumbasar and Aykol 1993). However, they hardly grow into gem size and quality. In Turkey, type locality is Milas county (Muğla) (Lake Bafa vicinity and area in between Milas-Yatağan counties). There are reports on its existence in Söke (Aydın), Tire (İzmir), in central Anatolia (Gerdekkilise-Bolkardağ) and Saimbeyli county (Adana), however, these are not at mineable scale. Gem quality diaspores are mostly used in jewelry. Two names were adopted, also trademarks, for such diaspores, "Sultanite or Zultanite" in honor of Ottoman Sultans and "Csarite". It has very unique phenomenal color changing property and rarity thus becoming more popular. It is considered as "diamond of the future" by many.

\subsection{Sepiolite}

Sepiolite, also known as meerschaum, is a soft white clay mineral - a complex magnesium silicate, a typical chemical formula $\left(\mathrm{Mg}_{4} \mathrm{Si}_{6} \mathrm{O}_{15}(\mathrm{OH})_{2} \cdot 6 \mathrm{H}_{2} \mathrm{O}\right)$. It can be present in fibrous, fine-particulate, and solid forms. Sepiolite is opaque and off-white, grey or cream color, breaking with a conchoidal or fine earthy fracture, and occasionally fibrous in texture (Fig. 3). There many reports on its occurrence worldwide. It is generally associated with carbonate/evaporate sequences, sedimentary in origin. However, it also occurs in Kibrısçık (Bolu) as a result of hydrothermal alteration of glassy tuffs of Middle Miocene Deveören volcanics in Köroğlu (Galatya) volcanic belt (Irkeç and Ünlü 1993). Although there are occurrences worldwide, most of the sepiolite of commerce is obtained chiefly from Sepetçi, Marg1, Sarısu, Kayı, Gökçeoğlu, İmișehir, and Türkmentokat villages of the city of Eskișehir in Turkey. Nemli (Kütahya) is also important for its alike occurrences. It is mostly used to make pipes and small objects, paring beads. Calcite, gypsum and dolomite often company sepiolite.
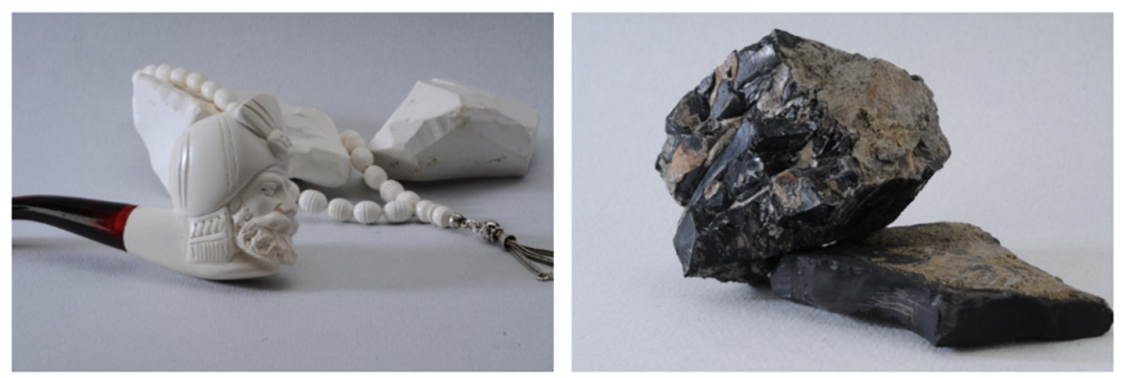

Fig. 3. Macroscopic views of worked and raw Eskişehirstone and raw Oltustone (Selim 2015)

\subsection{Jet/Oltu Stone}

Jet (literal name) or Oltustone (locality name), is an opaque black coalified fossilized drift wood of trees of the family Araucariaceae which is 180 million years old (Fig. 3). 
It is formed from the high-pressure decomposition of wood. Jet is chemically related to brown coal, or lignite, but it is more solid and tough, looks more like obsidian than a coal (Toprak 2013). Jet has been used both as a talisman and a jewel for over four thousand years. In Turkey, it occurs and mined in Oltu county (Erzurum) where more than 300 locations around Tutlu (Lispek), Yeșilbağlar (Norpet), Güllüce, and Güzelsu villages. Jet is also found in other locations around the world. However, only the British and Spanish deposits in addition to the Turkish occurrences have been worked commercially. Jet is called "Oltustone" in Turkey due to its type locality (Ciftci et al. 2004). It is mostly used in jewelry and to make praying beads. Framboidal pyrites and clay pockets commonly occur in jet.

\section{Conclusions}

Among the many, 6 semi-precious stones are the most common and renowned: smoky quartz, Eskișehirstone, Oltustone, sultanite, blue chalcedony, and Şenkaya emerald. Major use of these include jewelry (sultanite, Oltustone, smoky quartz, blue chalcedony, and Şenkaya emerald), ornamental objects (Eskişehirstone, Oltustone, smoky quartz, blue chalcedony, and Şenkaya emrald), prayer beads (Oltustone, blue chalcedony, and Eskișehirstone). Sultanite (diamond of the future) is a rising star in the precious stones due to its only occurrence in Milas area (Muğla) and unique properties.

\section{References}

Ciftci E, Yalcin MG, Yalcinalp B, Kolaylı H (2004) Mineralogical and physical characterization of the Oltustone, a Gemstone Occurring around Oltu (Erzurum-Eastern Turkey). In: 8th ICAM, São Paulo-Brazil, pp 537-538

Hatipoğlu M, Babalık H, Chamberlain SC (2010a) Gemstone deposits in turkey. Rocks Miner 85 (2):124-133

Hatipoğlu M, Türk N, Chamberlain SC, Akgün AM (2010b) Gem-quality transparent diaspore (Zultanite) in bauxite deposits of the Ilbir Mountains, Menderes Massif. SW Turk Miner Deposita 45(2):201-205

İlhan NN (2012) Türkiye'nin Mücevher Taşları Haritası. I. Türkiye Mücevher Taşları Sempozyumu, Bildiriler Kitabı, İstanbul, pp 33-38

İrkeç T, Ünlü T (1993) Volkanik kuşaklarda hidrotermal Sepiyolit oluşumuna bir örnek: Kıbrısçık (Bolu) Sepiyoliti. MTA Dergisi, Ankara, vol 115, pp 99-118

Kumbasar I, Aykol A (1993) Mineraloji. İstanbul Teknik Üniversitesi Kütüphanesi, Sayı: 1519, İstanbul 
Selim HH (2015) Türkiye'nin değerli ve yarı değerli mücevher taşları. İstanbul Ticaret Odası (ITO) Yayınları No: 2014/4, 102s, İstanbul

Toprak S (2013) Petrographical properties of a semi-precious coaly stone, Oltu stone, from eastern Turkey. Int J Coal Geol 120:95-101

Open Access This chapter is licensed under the terms of the Creative Commons Attribution 4.0 International License (http://creativecommons.org/licenses/by/4.0/), which permits use, sharing, adaptation, distribution and reproduction in any medium or format, as long as you give appropriate credit to the original author(s) and the source, provide a link to the Creative Commons license and indicate if changes were made.

The images or other third party material in this chapter are included in the chapter's Creative Commons license, unless indicated otherwise in a credit line to the material. If material is not included in the chapter's Creative Commons license and your intended use is not permitted by statutory regulation or exceeds the permitted use, you will need to obtain permission directly from the copyright holder. 